\title{
Turkish Banks and Digitalization: Policy Recommendations from a Qualitative Study
}

Ahmet Coşkun Yıldırım*

\begin{abstract}
Digitalization, as a popular issue in banking, is changing the way of doing business with new business models resulting in a change in employment structure, business development and sales/marketing. Digital platforms utilize operational efficiency, data intensive and even artificial intelligence driven risk management and decision making processes. This change has led to repercussions in organizational structures of banks, sectoral regulations and policy development perspectives. With respect to that, in this study, structured interviews are conducted with seven Turkish top bank managers to provide feedbacks and policy recommendations from the field that support the aforementioned change in banking.
\end{abstract}

Keywords: Digitalization, Turkish banking, New regulations, Policy recommendations.

JEL Classification: G20, G28.

\section{Öz - Türk Bankaları ve Dijitalleşme: Nitel Bir Çalışmadan Elde Edilen Politika Önerileri}

Bankacılıkta popüler bir konu olan dijitalleşme yeni iş modelleriyle iş yapma biçimini değiştirmekte, bu yeni iş modelleri istihdam yapısında, iş geliştirme ve satış/pazarlamada değişimlere neden olmaktadır. Dijital platformlar, operasyonel verimlilik, veri yoğun ve hatta yapay zeka odaklı risk yönetimi ve karar verme süreçlerini kullanırlar. Bu değişiklik, bankaların örgütsel yapılarında, sektörel düzenlemelerde ve politika geliştirme perspektiflerinde yankı uyandırmıştır. Bununla ilgili olarak, bu çalışmada, yedi adet bankanın tepe yöneticileri ile yapılandırılmış görüşmeler gerçekleştirilmiş olup, bu görüşmelerle bankacılıkta söz konusu değişimi destekler nitelikte sahadan geri bildirimler ve politika önerileri almak amaçlanmıştır.

Anahtar Kelimeler: Dijitalleşme, Türk bankacılığı, Yeni düzenlemeler, Politika önerileri.

JEL Sınıflandırması: G20, G28 * Middle East Technical University, M.Sc., Science and Technology Policy Studies - E-mail: ahmetcoskunyildirim@yahoo.com
ORCID ID: https://orcid.org/0000-0003-0398-5565

Article Received: 05.11.2020

Article Accepted: 01.12.2020

DOI: 


\section{Introduction}

Technological developments are causing radical changes in many sectors in an increasing pace with important effects of efficiency and profitability resulting in new business models that have changed sector competition and banking paradigm. These developments also provide decreases in costs of operation and increases in customer basis and profitability which result in efficiency, utilization of lesser inputs for producing more outputs in banking (Özel et al., 2017). Banking and finance is the most obvious sector utilizing the benefits resulting from financial innovations.

Oslo Manual defines innovation as the implementation of a new or significantly improved product (good or service), or process, a new marketing method, or a new organizational method in business practices, workplace organization or external relations with reference to product, process, marketing and organizational innovations (Oslo Manual, 2005). Mainly, by using the definition of innovation, it is somehow possible to name significant changes in financial instruments, services, and markets as financial innovation (Comert and Epstein, 2016). These changes may stem from differing characteristics such like cost minimization, operational efficiency, risk management, development of new financial products etc. Definitions of financial innovation vary with reference to their goals, structure of legal framework and market demand and opportunities. Therefore, financial innovation may include product and/or process innovation.

Customers are main drivers of financial innovation with the variety and volume of their demand. The interaction of demand and supply as developing the innovative skills of providers is a historical fact accompanied with the regulatory framework which plays a very crucial role in determining the context, boundaries, and path of financial innovation. With the increasing pace of information and communication technologies, banks and financial institutions can receive prompt feedbacks from the market with reference to changing and differing demand. The constant interaction of all the parties (banks and financial institutions as providers, customers, and regulatory authorities) result in product, process and business model innovation in a certain time. Therefore, the concept of financial innovation has an inclusive content. This inclusiveness has repercussions in considering digitalization and financial innovation as embedded in each other.

Digitalization, as a crucial means of instant banking and finance operations provides ground for a more dynamic demand and supply interaction which results in an increased variety of financial innovations that are product, process and business 
model innovations. In a sense, digitalization is a major milestone, a paradigm advancing or shifting phenomenon in the context of financial innovation. It is the transformation of banking, finance and money that is witnessed by means of digitalization as a financial innovation.

Digitalization by itself is not only a process innovation that provides operational efficiency or a product innovation that provides new financial instruments but it is also a business model innovation due to the fact that digitalization and big data changes the rules of the game. Therefore, digitalization from a macro perspective is to lead more collaboration among actors in the finance and transformation of value creation in a more data analytics-based manner. In sum, during the digitalization process through the emergence of new financial instruments, operational efficiency and product innovation issues came up naturally for the banks. Hence, it is hard to say whether digitalization leads product innovation or not since they emerged simultaneously in the market. However, after the digitalization process existing business models have changed.

With the utilization of digitalization and digital technologies, financial innovation entered a new era defined as the prompt interaction of financial sector companies and customers by means of customer feedbacks, together with increasing collaboration and interaction of financial sector companies. Conventionally, branches are main distribution channels of banking. However, with utilization of technology, alternative distribution channels emerged initially with automated teller machines (ATM). Alternative distribution channels, including mobile devices, digital TVs as well as internet banking, are attractive to banks because of the advantages they provide (e.g. cost cutting, efficiency and better service quality). Digitalization provided a paradigm shift in banking towards intensive utilization of so-called alternative distribution channels.

As the level of digitalization is increasing, codified knowledge base is expanding as a result and this gives way to utilization of various instruments regarding data analytics and decision-making processes. The most prominent of these instruments is artificial intelligence (AI). With utilization of $\mathrm{Al}$ and many other instruments, a wide range of sectors benefit from increasing efficiency and profitability that have economic development effects (Accenture, 2017). We see penetration of Al more and more in banking and finance (Yıldırım, 2019).

As a result of digitalization and utilization of $\mathrm{Al}$ in banking and finance, value creation is changing in a more efficient way. These issues are repercussion of the

A. C. Yıldırım, "Turkish Banks and Digitalization: Policy Recommendations from a Qualitative Study", Journal of BRSA Banking and Financial Markets, 14, (2), 2020, 145-174 
strong correlation between financial market development and economic growth. Hence, technological and financial innovations are amongst underlying factors of economic growth. In this respect, financial innovations, as a key concept for an efficient financial system, contribute to economic development with effective channeling of funds for development and by converting the companies to a more efficient and technology intensive business model (Akhavein et al., 2005).

Based on these aforementioned facts, it is understood that, the role of financial innovation, as induced by digitalization, is very important for efficiency and thus improving productivity. Therefore, the pace and quality of its diffusion matters and faster the diffusion of innovation, more immediate the social and economic impact it causes. In this respect, this study is about policy recommendations with regards to changes and scenarios in the future of banking and finance with respect to major business model changes due to digitalization.

The aim of this study is to explore the effects of digitalization and the digitalization-based changes on Turkish Banking Sector (TBS) for the sake of policy development.

Turkey has a great potential for the growing banking technology. According to TURKSTAT, total population is 83,154,997 in the end of 2019 (Turkstat, 2020). The percentage of the population uses $93 \%$ of internet and mobile banking. According to Statista, the number of active mobile banking customers increased from 6.7 million to 32 million between 2014 and 2018 in Turkey (Cherowbrier, 2020). As can be seen from these statistics, Turkish digital banking is an interesting case to explore.

From this perspective, the main research question of the study is: "What are the main policy development areas in digitalization process of TBS?" To answer this question in depth, expert views become important to provide an overall picture, for that, structured interviews are conducted with the Vice Presidents and/ or Department Heads of banks in TBS. Vice Presidents like Chief Digital Officers or chief officers responsible for digital transformation processes are interviewed as respondents. Seven representative banks are comprised of private deposit banks, state-owned banks, participation banks, development and investment banks, foreign banks and branches of foreign banks as main types of banks.

The plan of the study is as follows: next section describes the conceptual framework. Following section gives information about the methodology. Namely, research approach, research design, and data collection method are explained in this section. 
Further, the grounds of structured interviews, selection of banks and respondents are stated. Section 4 discusses analysis and findings of the study. It is these findings and analysis signaling the unique contribution of this study and paving the ground for the next section that covers discussions and conclusions with policy recommendations.

\section{Conceptual Framework}

Main drivers of the digitalization in banking are namely competitive advantages, efficiency increase, prompt respond to customer needs and profitability. Macroeconomic factors, legislative issues, digital technologies, and their implementation in many other sectors lead digitalization to be a compulsory and inevitable process for banking industry (TÜSIAD et al., 2016). In this respect, main banking functions like information gathering, account opening, customer on boarding, day-to-day banking, expanding relationship and ending relationship are covered in the digital framework. By means of digitalization, banks provide a wider range of services in a time saving manner with reduced human involvement and errors. Banks face changes in value creation (Ditshego, 2018) in this context and this results in fast and efficient operation of the finance system and cost minimization of operational processes by substituting machinery and digital processes for people and simple automated processes.

Digital transformation also transforms business towards mobile, flexible, customer-centered base as focused on reshaping customer value propositions and transforming the operating model. In this respect, enhancing products and services for a better customer experience, extending offerings for new value streams, creating new digital capabilities, leveraging information to manage across the organization, integrating and optimizing all digital and physical elements and redefining core elements for a radically reshaped value proposition are important. Hence, business models started to change within banks with digitalization. More efficient back-office operations, internet and mobile banking provided a dynamic platform of interactions and feedbacks between banks and customers. Data-driven business models and analysis became an important part of finance industry. Companies having sound business models, adaptive skills, coherent digitalization strategy, better understanding and expectations of digital transformation of the markets and economy are more likely to avoid costly mistakes and failures and benefit from this process (Davenport, Westerman, 2018). 
In this respect, digitalization initially let in-house changes in business models of banks and financial institutions with increasing operational efficiency, internet and mobile distribution channels and decreasing human factor. Therefore, digitalization paved the ground for a more dynamic and changing era of financial sector with more interaction and collaboration of actors emerging as a main determinant of the change of the paradigm.

It is not only collaboration but also roles, business models and interactions between actors that are facing a change, a paradigm shift due to digitalization. From the perspective of traditional banking and legal framework, data privacy and secrecy are main concerns regarding digitalization. However, the pace of digitalization caused a paradigm shift to open banking in a platform-based business approach where interactions and value exchanges are facilitated like in old ancient marketplaces. Therefore, in open banking, data, processes, and business functionalities are made available within an ecosystem of customers, third party developers, FinTech startups, or partners. The services provided are financial and may come from banks as well as from third parties. Data sharing, accessibility, shared values, and collaboration are the main concepts defining open banking paradigm.

Following open banking, another platform-based business approach that is named as "beyond banking" emerged. There are different service providers providing multiple services to customers in this approach. These services are provided in an integrated and harmonious manner. The range of the content of these services have a large variety (e.g. mobility, security, delivery, home security) and banks can be part of this procurement process by providing niche and tailored financial services that consistently integrate the scope of services. This is the vertical integration that is the strategic part of value creation in a more competitive banking business environment. For value creation and benefit optimization, a vertical integration of operational process with specialized partners having cost efficiency in each step of business is of strategic importance. (Deloitte, 2018).

Open banking and beyond banking concepts set-up the bank of the future model in a respective manner. In open banking, banking providers do perform business in banking platform with data sharing and accessibility resulting in collaboration. Banking Provider refers to a leading supplier of (certain) financial services through third party platforms. In this respect, banking providers are comprised of banks, other financial institutions, third party developers, FinTech companies etc. Hence, Banking Platform is a digital platform where supply and demand, in other words providers 
and customers meet, where the banks or third party financial products and services are offered to the bank's customers. With beyond banking concept, banking platform transforms into an exponential platform which is developing and owning a digital platform where all types of (connected) services are offered to customers in a coherent manner (Deloitte, 2018) with respect to aforementioned vertical integration. Due to this vertical integration, banking providers and service providers are together in the ecosystem. This paradigm shift is displayed in Figure 1 below.

Figure 1: Bank of the future model

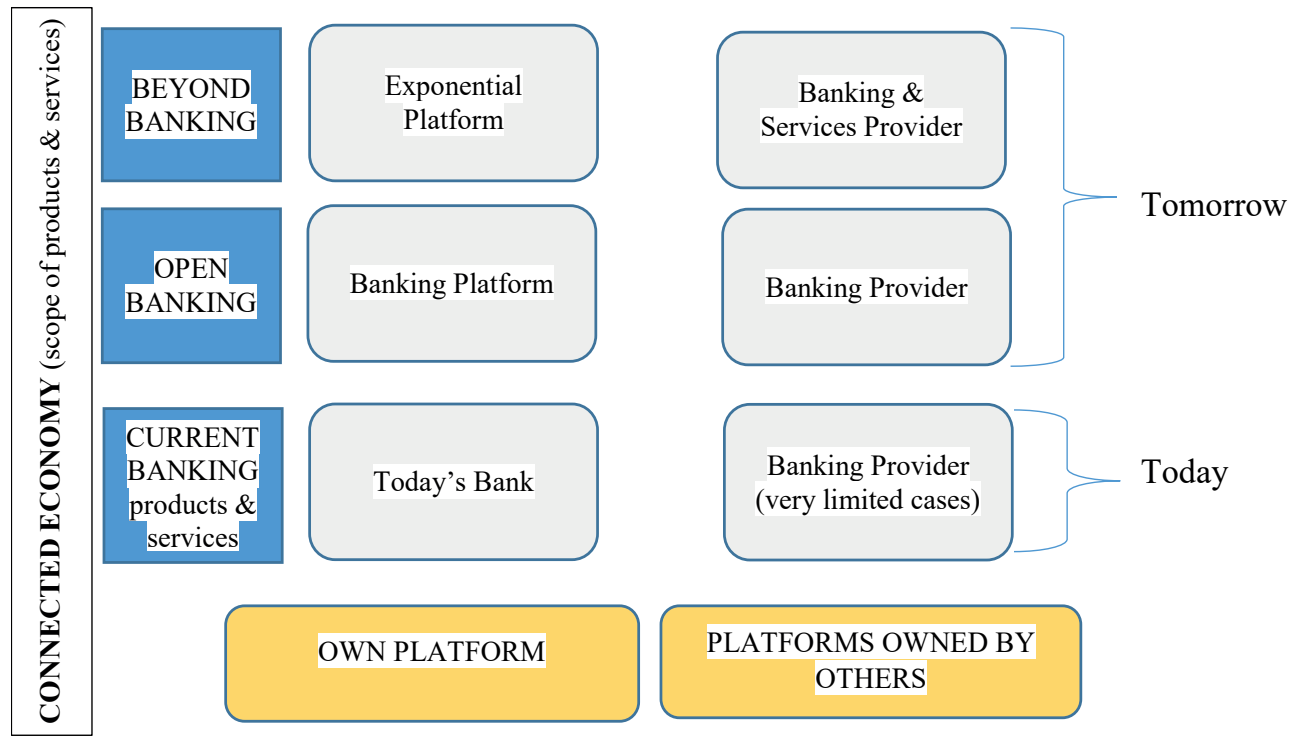

Source: Deloitte Bank of the Future Report (2018)

As seen from the figure, connected economy includes scope of products and services whilst connected customer contains control of client relations, distribution channels and ecosystems. Connected economy displays current banking products and services of today, open banking and beyond banking of tomorrow. Connected customer covers own platform and platform owned by others. In this respect, current banking products and services of today have today's bank as own platform and banking provider as platform owned by others. Open banking of tomorrow has banking platform as own platform and banking provider as platform owned by others. Finally, beyond banking of tomorrow has exponential platform as own platform and banking and services provider in a more comprehensive manner. 
Increasing competition in banking and finance sector shapes the future of this new business model with increasing need for collaboration. For example, it is crucial for FinTechs not to stay behind digital champions and develop further in the direction of exponential platforms for this goal. As customer demand shifts towards more complex banking products, they need to broaden the extent of their services in traditional banking services to meet this dynamic demand. This necessitates collaboration with banks and other specialized FinTechs. Increasing and dynamic collaboration and interaction correspond to the aspects of the future of banking named as beyond banking. Open innovation, sharing economy and shared marketplace in a data-intensive manner define the future paradigm.

Dynamic character of future paradigms for finance sector has repercussions in the emergence of a following concept, Open $X$, which is a common platform, in a sense a shared marketplace and actors of this platform are in a data-intensive framework with extensive utilization of data. Another major characteristic in this platform is collaboration among actors for the sake of the quality and sustainability of their services (Capgemini, EFMA 2019). This new paradigm forces actors to change their business model culture and technology architecture by leaving outdated business patterns and starting a radical digital transformation.

The future of banking business, defined by a common platform or a shared marketplace, is a phenomenon that actors of the ecosystem should consider as beyond open banking to remain in the ecosystem. The existing actors of the ecosystem, banks have extensive resources, networks of huge volumes of customers. On the other hand, FinTechs, as more recent actors of the ecosystem, are more flexible in their business models and methods and have a more entrepreneurial consideration, a start-up spirit together with their human-centered design expertise and technological capabilities. Thus, partnerships and collaborations will result in a win-win situation in this respect when these peculiarities are considered.

In this paradigm defined by partnerships and collaborations of actors in the ecosystem, with the utilization of technology, tailor-made financial services and customer feedbacks define the crossroads of customer experiences of financial services. This new paradigm is defined by the shift of the focus from products to customer experience, from assets to data centered approach, from ownership to shared access and from buying or building to partnering.

Application Programming Interfaces (APIs), a software intermediary that allows two applications to talk to each other, are utilized in open banking and are crucially 
important means in the Open $X$ environment. APIs, as drivers of innovation, provide flexibility to the actors to develop the quality of the customer experience and to provide prompt launching of products. As the industry moves towards an open architecture and as API recognition enhances, ecosystem players must utilize the use of standardized APIs in order to help reducing fraud, improving interoperability and increasing scalability. APIs are not only used by banks and Fintechs, but also by BigTechs like Google, Amazon etc. for integrating or monetizing services. APIs, information and information structure are important components of Sharing Economy that emphasizes the role of collaboration.

Open $X$ environment is also defined with a shift of financial services having four pillars (Capgemini, EFMA 2019). The first pillar is the shift of focus to customer experience (vs. products). Transition from traditional banking to digital banking, digital banking to open banking and open banking to Open $\mathrm{X}$ is to be mentioned in this context. Products, ownership, build/buy and assets are respectively replaced by experiences, shared access, partner and data in Open X environment. Consent and trust with respect to data driven and data intensive business are main concepts in this manner. That is to say, trust of customers to banks and their data, which can be quitted by customers easily, define the consent economy and in this respect, banks must be able to integrate their services without any problems. The second pillar is evolving of data as a critical asset. With the evolution of "big data" as a major asset in data-driven economy, strategic utilization of data to benefit from new revenues, creating value and enhancing intuitive decision-making are main issues. Increasing volume of data and the need for data analysis let to utilization and adaptation of Artificial Intelligence (Al) in financial services for understanding customer needs better, prompt and precise analysis and decision-making and thus transforming the business culture towards that of start-ups in a dynamic manner.

Partnering of firms instead of unilaterally developing and purchasing capabilities is the third pillar. In this respect, to deliver value to end customers, Open X will force the pace of partnerships between the actors like banks, FinTechs and others for a more efficient ecosystem. It is important to have an encouraging and broadly skilled ecosystem to overcome challenges like data privacy, barriers due to regulatory framework, fraud, preclusion of the trust of customer and channel expertise. Shared access is the fourth pillar which is due to capabilities and asset ownership. Partnerships in the ecosystem will cause the transformation of ownership to a shared economy. Exploring the opportunities of shared economy following Uber and Airbnb has been a common situation in many industries. As a result, there emerges

A. C. Yıldırım, "Turkish Banks and Digitalization: Policy Recommendations from a Qualitative Study", Journal of BRSA Banking and Financial Markets, 14, (2), 2020, 145-174 
new product development and distribution opportunities due to in-house efforts or partnerships with other actors in the developing financial sector ecosystem. In this respect, the shift from competition to collaboration in the financial ecosystem stems from structural collaboration. Elements of effective collaboration are people, finance, business and technology.

Consequently, digitalization and its effects as a major paradigm shift in the ecosystem are stated above. With considering these changes and related literature, the qualitative study comprised of structured interviews is structured and conducted. The methodology of this qualitative study is stated in the following section.

\section{Methodology}

To understand the effect of digitalization and related policy recommendations on Turkish Banking Sector (TBS), a qualitative study (Patton, 2002) comprised of structured interviews are conducted. All interviewees are asked the same, pre-established, questions in order to minimize researcher bias and increase generalizability of the findings $(\mathrm{Qu}, 2011)$. The interviews are conducted on Zoom due to Covid-19 pandemic. Representing all the groups of banks in TBS, different banking groups like state-owned banks, private deposit banks, Islamic participation banks, medium-sized banks and foreign banks are considered in this study. Seven representative banks selected in this study in terms of bank types are based on the tradeoff between the quantity of cases and in-depth studying (Kalling, 1999). Also, when selecting the banks, attention was paid on having a variety instead of a large amount of banks as has been done in various previous studies (e.g. Gsell and Mette, 2017). Selected banks are listed as: Bank A - medium scale foreign deposit bank; Bank B - big scale private deposit bank; Bank C - medium scale participation bank; Bank D - state development bank; Bank E - big scale private deposit bank; Bank F - medium scale private deposit bank; Bank G- medium scale state-owned deposit bank.

One bank from each banking group, as a relevant sample size represents the TBS in a sound manner. Banks are selected in accordance with the classification of Banking Regulation and Supervision Agency (BRSA). Asset share of selected banks in the study comprise about 40\% of Turkish Banking Sector as of 2019 year-end. This sample size, in terms of covering different types of banks in the sector, as classified by BRSA, and covering the $40 \%$ of assets of TBS is a reasonable and saturated sample for the sector. More interviews with other banks have started to be iterations of findings of this study, in this regard due to the saturation level of the sample, the sample size is kept as seven diversified banks (Patton, 2002). 
Selection criteria of the interviewees were mainly relating to their position in leading and managing the digitalization strategy and process of their banks. Therefore, all participants are in the top management positions responsible from and/or closely related to strategy and digitalization in their banks. They are either Vice-Presidents or Department Heads responsible from digitalization, digital transformation, alternative distribution channels and/or IT systems so that they provide not only perspective of their banks but also an overview of the industry together with projections for future regarding the industry and their bank.

\section{Analysis and Findings}

The data collected through a structured interview is analyzed using the pattern-making approach presented by Yin (2014). Quotations derived from interviews and related analysis are stated below with respect to certain topics.

\subsection{Digitalization and Sector Competition}

Digital transformation has started in Turkish banking sector around 2015-2016 as stated by Bank $A$.

BANK A "In 2015, we have started mobile banking in Turkey. For digitalization, there is no such a thing as one-size-fits-all."

As mentioned by Bank B and Bank C, Turkish banking has become one of the leaders in the world; better than US and Europe banking in terms of service quality and variety, especially in the retail banking operations (Bank F). In fact, the installment option to credit cards is one of the inventions.

BANK B "Turkey is in front of Europe and US in terms of service quality in banking. Our customers are spoiled. This is a demand-driven sector."

BANK C "Turkish banking sector is much better than Europe and US in terms of product variety. For example, installment to credit card is our invention"

BANK F "Retail banking is faster than corporate banking in digitalization."

In fact, as stated by Bank E, Turkey has 56 million digital banking users of which 44 million of them are using mobile banking.

BANK E "There is digitalization index 2016 of Accenture and accordingly, Turkey in general is $61 \%$, for financial companies $81 \%$. Turkish retail banking digitalization has a leading role in the world. By January-March, according to banking association,

A. C. Yıldırım, "Turkish Banks and Digitalization: Policy Recommendations from a Qualitative Study ", Journal of BRSA Banking and Financial Markets, 14, (2), 2020, 145-174 
there are over 56 million digital banking of which 44 million are using mobile banking. It is an important sales channel".

"First digitalization was a channel change, now it is the main channel"

As a customer demand-driven sector, stated by Bank F, after digitalization, the competition has been based on service instead of price. The channels of providing services have been changed to digital platforms, mainly internet and mobile phones and due to the expectations and necessities of the consumers, the priority is given to seamless and personalized services (Bank B). As Bank D states, customers can easily change service providers according to their expectations.

BANK F "There is customer driven competition"

BANK B "New developments in technology brought radical changes. Specifically, as the internet and mobile phone usage has become an important part of our daily lives, individuals' expectations and necessities with their interactions with financial institutes have changed."

"Now services provided out of the banks should be seamless"

"There is a need to design personalized solutions and proposals. As the life expectancy has increased, there are new and niche segments that need extraordinary solutions"

BANK F "Before digitalization, competition was based on price, now it is based on service. People want to get good service, fast accessibility, and trustful environment; we were focusing on product before; now we focus on customer"

BANK D “Digitalization provided customer base enlargement as customers are quick to shift towards institutions with faster operations."

One main effect of digitalization of the sector has been providing high quality, fast, personalized, accessible services, the other is the reduction in the number of branches. The number of branches has decreased from 12.000 to 10.000 in the last few years.

BANK B "...the effect of digital transformation banks has started to close their branches between 2017-2019"

BANK F "Digitalization fastens and ease processes: customers' operations diversification and makes them paperless. In the long run, I think banking will be without 
branches. I cannot think of our children going to branches to pay electricity, gas bills, transfer money, buy currency etc. Branches may only be used for consultancy"

"We have a digital financial portal that uses no branch operation, which has been very beneficial during pandemic"

"For the last few years, the number of branches has decreased from 12.000 to 10.800"

BANK G "In banking, digitalization brought branchless banking. We try to provide trustful, fast and user-friendly customer experience through internet and mobile banking"

With the decrease in the number of branches, more operations have to be handled through the digital platforms. That has brought the need of fast, trustful, innovative solutions to customer expectations, which is front desk operations, and also a new organizational system, back desk operations. To achieve this digital transformation, banks have started to use Al.

BANK G "Digitalization is transformation of knowledge and data to digital and it affected not only the product but also the whole system"

BANK B "Now, Al is the trend"

"Artificial intelligence, non-intermediary systems etc. affect doing business in the financial world"

One additional effect of $\mathrm{Al}$ also has been on digital marketing as mentioned by Bank D. Therefore, besides operational processes and service quality, Al is increasing the quality of competition by digital marketing.

BANK D "Retail banks started using Al. We are starting to use Al in pop-ups and digital marketing in our bank."

New technology usage in the financial system has brought a new challenge to the competition. Banks have started to compete to provide new service channels and adapt/restructure their organization to the new digital world. That has created a necessity to cooperate with other technology and data driven companies such as Fintechs and technology firms.

BANK A "Digitalization is there, in some cases as leapfrog, in some slower. Maturity differs from one country to another, for example, Fintech is growing much high-

A. C. Yıldırım, "Turkish Banks and Digitalization: Policy Recommendations from a Qualitative Study", Journal of BRSA Banking and Financial Markets, 14, (2), 2020, 145-174 
er in China than any other country due to its market, population, and social status."

BANK B "In Europe there is Payment Services Directive, Open Bank Standards, Opening APIs for Fintechs that create competition risk as threats to payment services, asset management, and financial consultancy services of banks"

"In US there is GAFAM (Google, Amazon, Facebook, Apple and Microsoft) and in Asia there is BATPJ (Baidu, Alibaba, Tencent, Xiaomi, PJ Pingan and JD) as the giant technology firm competing aggressively against banks due to their collected data size, customer network and their expertise in $\mathrm{Al}^{\prime \prime}$

Turkey, as one of the leaders of the global banking sector in terms of product variety and quality, has been behind many countries in cooperating with other financial institutions. In the first decade of 2000s, due to investments for the adaptation of recent banking technologies, TBS was mentioned among the leaders in global banking sector as stated in the interviews. However, due to lacks in collaboration with Fintechs and other actors, TBS failed to create an innovation system and consequently, Turkey has been behind many countries as mentioned in the interviews.

BANK F "Yet, we do not have enough cooperation with Fintechs. We are followers in that respect. If we put Al maturity level on a scale of 1-5 (1 lowest, 5 highest), our sector is $2^{\prime \prime}$

\subsection{Policy Recommendations}

There have been some improvements in regulations to ease the adaptation process to digital transformations and Covid-19 period. For example, as Bank B states, some regulations promote financial technology, crisis management and Development Plan covering the issues of e-government and ID verification system to ease the adaptation of customers and banks to new technologies. Digital transformation of regulations in accordance is very important for ensuring the diffusion and adaptation of new technologies.

BANK B "Regulations are promoting financial technology usage and increase competition in this area".

"In Turkey, in the Development Plan, there are actions for diversifying financial institutions, developing e-commerce, retail chain, e-government open data and ID verification systems".

"The first reaction to 2001 crises makes the system stay on its feet". 
BANK C "Opening Digital Transformation Office and e-government portal by the government is good in terms of awareness".

As Bank F states, banking sector is in front of many countries in product variety and can be better if new regulations are adapted. For example, easing bank account opening by developed ID confirmation systems and harmonization of legal framework with respect to digital transformation.

BANK F "Turkish banking sector is good in terms of technology, innovation, product diversification compared to Europe and US. However, it can become a leader if regulatory side is also adapted".

According to Bank B and E, Turkey needs government support for open banking. Convergence of legal framework with flexibilities for data sharing in TBS is a major issue. Legal framework restricts data sharing. However, harmonization of legal framework to digital transformation with flexibilities in data sharing, developed ID verification systems and substituting the need for physical signature are stated as main support from government in terms of adapting legal framework in this manner.

BANK B "China, UK, US... all have open banking structure. Turkey could not step forward and get behind. Turkey is not like China. China has a large scale, product has a big chance of being successful. For us, we need government supported fragmentation and specialization"

BANK E "The future is open banking and our country is in its initial stage. We need to share data with other institutions and this stage needs new regulations."

"Regulations slow down the innovation process of banks" (Jakšič and Marinč, 2015; Vasiljeva and Lukanova, 2016). Bank B states that capital restrictions and controls and restrictions related to data sharing limit the improvements in innovation.

BANK B "In Turkey, there are limitations due to regulations. From now on even bills will not be sent through email. Capital restrictions and controls prevent innovation improvements".

"In the foundation of Al, there is data. In Turkey, according to the legislations, data should stay inside the country. For that reason, we could not utilize related cloud technologies and architects." 
Bank B and E mentions the importance of the role for unionized and secure structure of labor market for banks.

BANK B "For the workforce, there has to be a sound union structure, employee focused culture and instead of firing there can be a retirement option".

BANK E "Our service necessitates legislative responsibilities in terms of work security and with covid-19 life security."

As Bank E, C, and A state for new technology (blockchain and digital money) adaptation, especially for corporate banking, as Bank F mentions, which is not as fast as retail banking in digitalization, new regulations that ease the operations to use new technologies and trustful environment have to be made.

BANK E "For blockchain and digital money, it is early to say something because traditionally government prints money. Of course, in economy these will be placed somehow, active reactive management, regulations, limitations will determine our activities"

BANK C "For blockchain usage, there are question marks about having a guarantee by the government. For example, if I use blockchain for land registry system or smart contracts, will the government accept this, or will Central Bank accept money transfers by blockchain?"

BANK A "Only the one on the top that has the control can temple of blockchain. Trust is a big issue. This is nationwide governmental strategic decision"

"Digital money is also a national strategy. Central banks play key role"

BANK $F$ "Corporate banking is not as fast as retail banking in digitalization. To catch up, government should have new legislations."

In fact, as Bank $F$ explains, some operations do still need physical signature. E-signature usage should be encouraged by building safe and standardized environment with regulations. Also, this paper based, time consuming and sometimes untransparent processes can be costly for advisory/supervisory authorities during the investigation period. In addition, Bank C mentions the importance of flexible regulations in some instances such as having an easier process for long distance account openings and/or opening a branch.

BANK F "For example, onboarding has been our agenda, becoming customer 
process. We still need wet signature. This (e-signature) has passed as a regulation in the parliament but still should be supported by BDDK and MASAK to be safe"

"Organizational processes have been digitalized even the supervisory controlling activities. There is no document or wet signature anymore, supervision process has been shortened"

BANK C "We still cannot open a bank account for long distance. We have problems with AML (Anti-Money Laundering) and related KYC (Know Your Customer). We need more flexible regulations. Otherwise, technology companies for example mobile operators will be adapted very fast and start to give credits, open accounts etc."

"BigTech, Techfin are threat for us. We have some regulatory limitations in this competition. For example, we need the permission of BRSA to open a branch but BigTechs do not need this kind of permission."

Also, Bank D mentions the need of harmony in legislative framework for the sake of digital transformation. As mentioned above, Civil Law, Law of Obligations, Commercial Law and Banking Law should be amended to include digital signature in harmony with the digital transformation of working life, business and personal lives. In this respect, as opening bank account transforms to a digital operation, a major obstacle in digitalization of banking would be overcome.

Next section discusses these findings and analysis with policy recommendations and conclusion.

\section{Discussion, Policy Recommendation and Conclusion}

As the interviews with the selected banks show in this qualitative study, digital transformation has gained pace in Turkish Banking Sector by 2015 onwards. But with underlying grounds, the real transformation started by the second decade of the millennium. In parallel with the rapid diffusion of smart phones with 36 technology by 2001 onwards, first digital applications emerged. By these years, Turkish banks already began to adapt internet banking with late 1990s and early 2000s. The increasing volume of internet banking (Tekeli, 2017) was accompanied with WAP banking services provided by Turkish banks with an increasing wide range of services (Türkoğlu, 2002).

Rapid adaptation and diffusion of internet services and development of WAP banking technologies provided a prompt adaptation and learning process for cus-

A. C. Yıldırım, "Turkish Banks and Digitalization: Policy Recommendations from a Qualitative Study", Journal of BRSA Banking and Financial Markets, 14, (2), 2020, 145-174 
tomers. As mentioned in interviews, the paradigm of competition shifted from price competition to providing prompt and qualified services in Turkish Banking Sector. Besides, this paradigm shift, to maintain and develop their brand value, banks were facing pressure to be pioneers or not being laggards in adaptation and provision of new technologies (Türkoğlu, 2002). In this respect, as a repercussion of domino effect, the increasing adaptation of internet services, e-trade and digital services paved the ground for development of basic mobile applications, WAP banking and respectively, the competition in Turkish Banking Sector forced banks to rapidly adapt and provide these services to customers.

Customer demand as a driving force was one of the reasons of this adaptation of digital technologies. Another reason for this dynamic competition structure of Turkish Banking Sector was the ability of Turkish banks to invest in digital technologies to be pioneers in the sector in the first decade of 2000s. Due to stringent financial policy and supervision mechanism, Turkish Banks had strong capital adequacy ratios during the financial turmoil in that decade which paved the ground for investment appetite for new technologies. When product variety, customer satisfaction and sector is considered, Turkish banks are strong in adapting and developing digital products and technologies in a demand-driven manner. Hence, Turkish banking gained global significance in terms of service quality, product development and rapid adaptation of demand-driven digital technologies. The role of Turkish banks as early adapters or leaders is also emphasized in interviews.

However, until recent years, Turkish banks were mostly utilizing in-house resources for development of products and utilization of digital technologies as pointed in interviews. From 2015 onwards, we begin to see emergence of Fintechs and an eco-system with actors other than banks. Insufficiency of collaboration between banks, Fintechs and other technology companies is the recent problem of Turkish Banking sector for losing the global leading role and becoming a follower in this process. We need to see a more dynamic collaboration between banks, Fintechs and other technology developers in an eco-system for Turkish banking sector. That is to say, besides being strong in adapting digital technologies and changes, it is important to have a sound eco-system, an effective system of innovation with interactions and collaborations among actors to have a pioneer and leading role globally in digital competition as digitalization is not only an operational innovation but instead a new paradigm as pointed out in interviews.

To set up such a system of innovation, banks, government authorities, The Bank's Association of Turkey and/or other actors should have leaded banks and Fintechs to enhance collaboration networks. Turkish banks already have a history of collabora- 
tion with each other as in the examples of sharing POSs and ATMs for operational cost minimization. But on the contrary, Turkish banks lack in collaboration with Fintechs and other companies to be able to compete with technology companies. In terms of inter industry vs. intra-industry collaboration, the deficiency in inter-industry collaboration is a repercussion of conservativism and lacks in understanding the philosophy of digitalization, its effect in business models, new challenges that digitalization brings and the importance of digital tools in new business model of banking. Hence, it is possible to state that, a serious and long-term consideration of digitalization as a radical innovation in banking and all services sector will bring more focus and investment on development of digital technologies, products and rapid adaptation of them in collaboration with other actors of innovation system. This will most likely result in customer base enlargement with utilization of these technologies and creation of new digital business models and services.

\subsection{Policy Recommendations}

Policy recommendations have a large variety of topics to be covered. However, it is initially important to consider and express planned policies related with the content of this study that are stated in 11th Development Plan that was issued by Strategy and Budget Department of Presidency of Turkey in 2019. Digital transformation is a strategic factor as stated in the Plan. Therefore, accelerating digital transformation, development of interfaces, standards, measurement methodology for digital transformation is emphasized in this context.

The formation of a safe financial technology (Fintech) ecosystem together with a road map for its development, legislative alignment with the EU Payment Services Directive-2 for strengthening open banking legal infrastructure, establishing Association of Payment Services and Electronic Money Institutions and Istanbul Finance and Technology Base, implementing blockchain-based digital central bank money are following related goals denoted in the Plan. Hence, considering the policy goals of the Plan, innovation systems approach is used for designing policy recommendations to overcome policy problems and related weak points stated in this study. Therefore, development of collaboration networks, transformation of legal system, developing entrepreneurship in TBS by supporting Fintechs, revising regulatory and supervisory framework from innovation perspective, competence building and harmonization of work-life in this respect are major policy recommendations that will be detailed with policy aims, policy tools and policy targets respectively.

Policy recommendations are stated in Table 1 in the following pages and then stated in related topics, respectively.

A. C. Yıldırım, "Turkish Banks and Digitalization: Policy Recommendations from a Qualitative Study", Journal of BRSA Banking and Financial Markets, 14, (2), 2020, 145-174 
Table 1. Policy Implications for Digitalization in Turkish Banking Sector

\begin{tabular}{|c|c|c|c|}
\hline \multicolumn{4}{|c|}{ Policy Problem: Insufficient inter-industry interactions and collaborations } \\
\hline Policy Recommentations & Policy Aims & Policy Tools & \begin{tabular}{|c|} 
Policy Targets \\
\end{tabular} \\
\hline \multirow[t]{4}{*}{$\begin{array}{l}\text {-Collaboration networks in TBS should be } \\
\text { developed. }\end{array}$} & $\begin{array}{l}\text { - Developing a Technological System of } \\
\text { Innovation in TBS. }\end{array}$ & $\begin{array}{l}\text { - Promoting perception of Fintechs and banks } \\
\text { as collaborators by joint activities and } \\
\text { projects. }\end{array}$ & $\begin{array}{l}\text { Having a sectoral innovation system with } \\
\text { strong interactions and collaborations among } \\
\text { stakeholders. }\end{array}$ \\
\hline & & $\begin{array}{l}\text { - BRSA is to have an innovation perspective } \\
\text { for TBS and prepare innovation strategy } \\
\text { documents with joint committees from sector. }\end{array}$ & $\begin{array}{l}\text { Becoming digital leader and reaching the } \\
\text { optimized digital maturity level in digital } \\
\text { transformation maturity model of this study. }\end{array}$ \\
\hline & & $\begin{array}{l}\text { - Penetration of universities and research } \\
\text { institutes to the eco-system should be } \\
\text { promoted by joint activities and projects. } \\
\text { - Joint working groups and committees } \\
\text { comprised of all stakeholders stated above in } \\
\text { the eco-system should be established. }\end{array}$ & \\
\hline & & $\begin{array}{l}\text { - Strategy and road map for a sectoral } \\
\text { innovation system for TBS should be } \\
\text { discussed and drafted by these joint working } \\
\text { groups and committees. }\end{array}$ & \\
\hline \multicolumn{4}{|c|}{ Policy Problem: Shortcomings and problems stemming from legal system that slow down the sectoral progress in digitalization } \\
\hline \multirow[t]{4}{*}{$\begin{array}{l}\text { - Legal System should be transformed in } \\
\text { harmony with digitalization. }\end{array}$} & $\begin{array}{l}\text { - Having a legal system in compliance with } \\
\text { digitalization process. }\end{array}$ & \begin{tabular}{|l|} 
- Revising and amending Civil Law, Law of \\
Obligations, Commercial Law and Banking Law \\
in accordance with digital transformation.
\end{tabular} & \multirow{4}{*}{\begin{tabular}{|l} 
\\
- Providing the legal basis of global \\
competitive advantage for TBS in \\
digitalization.
\end{tabular}} \\
\hline & & $\begin{array}{l}\text { - Adaptation of digital signature and smart ID } \\
\text { verification systems for customers in opening } \\
\text { bank accounts. }\end{array}$ & \\
\hline & & $\begin{array}{l}\text { - Revising competition law in accordance with } \\
\text { digitalization and new business models } \\
\text { stemming from this process. }\end{array}$ & \\
\hline & & - Revising legal framework for data sharing. & \\
\hline \multicolumn{4}{|c|}{ Policy Problem: The need for developing entrepreneurship in TBS in accordance with 11 th Development Plan. } \\
\hline \multirow[t]{4}{*}{$\begin{array}{l}\text { - Developing Enterpreneurship in TBS by } \\
\text { supporting Fintechs. }\end{array}$} & \multirow{4}{*}{$\begin{array}{l}\text { - Having a developed entrepreneurial } \\
\text { framework with knowledge spillovers and } \\
\text { interactions in accordance with systems of } \\
\text { innovation approach. }\end{array}$} & $\begin{array}{l}\text { - Setting-up a framework for interactions of } \\
\text { Fintechs with knowledge spillovers. }\end{array}$ & \multirow[t]{4}{*}{$\begin{array}{l}\text {-Utilizing the benefits of developed } \\
\text { entrepreneurship by means of Fintechs. }\end{array}$} \\
\hline & & - Promoting new start-up Fintechs. & \\
\hline & & $\begin{array}{l}\text { - Designing tax incentives and new funding } \\
\text { opportunities for start-up Fintechs in } \\
\text { collaboration with banks. }\end{array}$ & \\
\hline & & - Revising legal framework for data sharing. & \\
\hline
\end{tabular}


Table 2. Policy Implications for Digitalization in Turkish Banking Sector (continued)

Policy Problem: The need for a leading role in developing standards, sectoral strategy and road map for digital transformation and setting up a systems of innovation with a revised regulatory and supervisory framework from innovation perspective.

\begin{tabular}{|c|c|c|c|}
\hline Policy Recommentations & Policy Aims & Policy Tools & Policy Targets \\
\hline \multirow[t]{5}{*}{\begin{tabular}{|l} 
- Revising Regulatory and Supervisory \\
Framework from Innovation Perspective.
\end{tabular}} & $\begin{array}{l}\text { - Having a proactive regulatory and } \\
\text { supervisory framework from innovation } \\
\text { perspective in TBS. }\end{array}$ & $\begin{array}{l}\text { - Drafting sectoral innovation strategy and } \\
\text { developing innovation rankings and ratings } \\
\text { for banks. }\end{array}$ & $\begin{array}{l}\text { Having a sectoral innovation system with } \\
\text { strong interactions and collaborations } \\
\text { among stakeholders. }\end{array}$ \\
\hline & & $\begin{array}{l}\text { - Developing sectoral digital maturity level } \\
\text { models and rating banks in accordance. }\end{array}$ & $\begin{array}{l}\text { Having a dynamic innovation policy } \\
\text { development framework with active } \\
\text { participation of sector actors. }\end{array}$ \\
\hline & & $\begin{array}{l}\text { Organizing joint activities, seting-up study } \\
\text { groups and committees with participation of } \\
\text { sector actors for ranking and rating } \\
\text { innovative capacities of actors in TBS, } \\
\text { developing strategies for adaptation of } \\
\text { future technologies like AI, blockchain and } \\
\text { digital money. }\end{array}$ & \\
\hline & & $\begin{array}{l}\text { Developing standards for APIs and } \\
\text { implementation of other technological } \\
\text { developments in TBS. }\end{array}$ & \\
\hline & & $\begin{array}{l}\text { Collaborating with other banking regulation } \\
\text { and supervision authorities in an } \\
\text { international level for adaptation of various } \\
\text { policies in other countries from an } \\
\text { innovation perspective. }\end{array}$ & \\
\hline \multicolumn{4}{|c|}{ Policy Problem: Shortcomings and problems stemming from legal system that slow down the sectoral progress in digitalization } \\
\hline \multirow[t]{3}{*}{$\begin{array}{l}\text { - Legal System should be transformed in } \\
\text { harmony with digitalization. }\end{array}$} & $\begin{array}{l}\text { - Having a legal system in compliance with } \\
\text { digitalization process. }\end{array}$ & \multirow{2}{*}{$\begin{array}{l}\text { - Revising and amending Civil Law, Law of } \\
\text { Obligations, Commercial Law and Banking } \\
\text { Law in accordance with digital } \\
\text { transformation. } \\
\text { - Adaptation of digtal signature and smart } \\
\text { ID verification systems for customers in } \\
\text { opening bank accounts. }\end{array}$} & \multirow{3}{*}{$\begin{array}{l}\text { Providing the legal basis of global } \\
\text { competitive advantage for TBS in } \\
\text { digitalization. } \\
\end{array}$} \\
\hline & & & \\
\hline & & - Revising legal framework for data sharing. & \\
\hline \multicolumn{4}{|c|}{ Policy Problem: The need for developing entrepreneurship in TBS in accordance with 11th Development Plan. } \\
\hline \multirow[t]{4}{*}{$\begin{array}{l}\text { - Developing Enterpreneurship in TBS by } \\
\text { supporting Fintechs. }\end{array}$} & \multirow{4}{*}{$\begin{array}{l}\text { - Having a developed entrepreneurial } \\
\text { framework with knowledge spillovers and } \\
\text { interactions in accordance with systems of } \\
\text { innovation approach. }\end{array}$} & $\begin{array}{l}\text { - Setting-up a framework for interactions of } \\
\text { Fintechs with knowledge spillovers. }\end{array}$ & \multirow[t]{4}{*}{$\begin{array}{l}\text { Utilizing the benefits of developed } \\
\text { entrepreneurship by means of Fintechs. }\end{array}$} \\
\hline & & - Promoting new start-up Fintechs. & \\
\hline & & $\begin{array}{l}\text { - Designing taxincentives and new funding } \\
\text { opportunities for start-up Fintechs in } \\
\text { collaboration with banks. }\end{array}$ & \\
\hline & & - Revising legal framework for data sharing. & \\
\hline
\end{tabular}

\subsubsection{Development of Collaboration Networks}

Insufficient inter-industry interactions and collaborations are policy problem that necessitates development of collaboration networks for the policy aim of developing a system of innovation in TBS. Therefore, enhancing interactions and collaborations between banks, Fintechs, technology companies, regulatory and supervisory authority, universities and research institutes as stakeholders are main components of this policy aim.

A. C. Yıldırım, "Turkish Banks and Digitalization: Policy Recommendations from a Qualitative Study ", Journal of BRSA Banking and Financial Markets, 14, (2), 2020, 145-174 
In order to enhance these interactions and collaborations, policy tools are as such:

- $\quad$ Promoting perception of Fintechs and banks as collaborators by joint activities and projects.

- Regulatory and supervisory authority, BRSA, should have an innovation perspective for TBS and prepare innovation strategy documents with joint committees from sector.

- Penetration of universities and research institutes to the eco-system should be promoted by joint activities and projects.

- Joint working groups and committees comprised of all stakeholders stated above in the eco-system should be established.

- Strategy and road map for a sectoral innovation system for TBS should be discussed and drafted by these joint working groups and committees.

Policy target for TBS in this context is having a sectoral innovation system with strong interactions and collaborations among stakeholders.

\subsubsection{Transformation of Legal System}

Shortcomings and problems stemming from legal system in the operational process that slow down the sectoral progress in digitalization are policy problems that necessitate transformation of legal system in accordance with digitalization. Policy aim in this title is having a legal system that is door opening for digitalization and innovations in TBS.

Policy tools for such a legal system are stated below:

- $\quad$ Revising and amending Civil Law, Law of Obligations, Commercial Law and Banking Law in accordance with digital transformation.

- Adaptation of digital signature and smart ID verification systems for customers in opening bank accounts.

- $\quad$ Revising competition law in accordance with digitalization and new business models stemming from this process.

- Revising legal framework for data sharing.

Policy target in this context is to provide the legal basis of global competitive 
advantage for TBS in digitalization. Therefore, increasing pace of adaptations and developments in digitalization may attribute a leading role to TBS in digital globalization.

\subsubsection{Transformation of Legal System}

Shortcomings and problems stemming from legal system in the operational process that slow down the sectoral progress in digitalization are policy problems that necessitate transformation of legal system in accordance with digitalization. Policy aim in this title is having a legal system that is door opening for digitalization and innovations in TBS.

Policy tools for such a legal system are stated below:

- Revising and amending Civil Law, Law of Obligations, Commercial Law and Banking Law in accordance with digital transformation.

- Adaptation of digital signature and smart ID verification systems for customers in opening bank accounts.

- $\quad$ Revising competition law in accordance with digitalization and new business models stemming from this process.

- Revising legal framework for data sharing.

Policy target in this context is to provide the legal basis of global competitive advantage for TBS in digitalization. Therefore, increasing pace of adaptations and developments in digitalization may attribute a leading role to TBS in digital globalization.

\subsubsection{Developing Entrepreneurship in TBS by supporting Fintechs}

Entrepreneurship is an important phenomenon to be promoted as stated 11 th Development Plan. Hence, there is a need for supporting and developing entrepreneurship in financial sector in accordance with development goals. As a result, policy aim in this respect is having a developed entrepreneurial framework with knowledge spillovers and interactions in accordance with systems of innovation approach. Policy tools for developing entrepreneurship in TBS by supporting Fintechs are stated below:

- Setting-up a framework for interactions of Fintechs with knowledge spillovers.

A. C. Yıldırım, "Turkish Banks and Digitalization: Policy Recommendations from a Qualitative Study", Journal of BRSA Banking and Financial Markets, 14, (2), 2020, 145-174 
- $\quad$ Promoting new start-up Fintechs.

- Designing tax incentives and new funding opportunities for start-up Fintechs in collaboration with banks.

As a result, policy target in this context is utilizing the benefits of developed entrepreneurship by means of Fintechs. They are very dynamic and agile actors with high skills of adaptation and innovative capacities in the ecosystem. They are able to trigger banks for enhanced collaboration and develop a system of innovation with enhanced innovative capacity.

\subsubsection{Revising Regulatory and Supervisory Framework from Inno- vation Perspective}

The need for a leading role in developing standards, sectoral strategy and road map for digital transformation and setting up a system of innovation necessitate revising regulatory and supervisory framework from innovation perspective. Policy aim in this perspective is having a proactive regulatory and supervisory framework from innovation perspective in TBS.

In this respect, policy tools for revising regulatory and supervisory framework from innovation perspective are stated below:

- Drafting sectoral innovation strategy and developing innovation rankings and ratings for banks.

- Developing sectoral digital maturity level models and rating banks in accordance.

- Organize joint activities, set-up study groups and committees with participation of sector actors for ranking and rating innovative capacities of actors in TBS, developing strategies for adaptation of future technologies like Al, blockchain and digital money.

- Develop standards for APIs and implementation of other technological developments in TBS.

- Collaborating with other banking regulation and supervision authorities in an international level for adaptation of various policies in other countries from an innovation perspective.

Hence, policy targets in this context are having sectoral indicators, as rating and 
ranking of innovation for sector actors in solo basis and for sector in a consolidated basis, and a dynamic innovation policy development framework with active participation of sector actors.

\subsubsection{Competence Building and Harmonization of Work-Life}

With respect adaptation of technologies like $\mathrm{Al}$, the need for human factor in banking and mainly in-service sector decreases. Moreover, new technologies are prone to create employment problems in service sector and more specifically in financial sector. Hence, competence building and harmonization of work-life in TBS in accordance with digitalization and technological developments are policy aims in this context.

Policy tools for competence building and harmonization of work-life in TBS in accordance with digitalization and technological developments are stated below:

- Joint committees and working groups comprised of sector representatives, unions and state authorities should work together for developing strategies for competence building in TBS and coping with negative employment effects new technologies.

- Unions should be more active and in collaboration with TBS, together with universities in developing competence building academic programs.

- Collaboration of TBS with universities for developing curriculums and training their staff, forming bank academies like data academy etc.

- Framework of Labor Law need to be revised in accordance with new business models and work relations stemming from digitalization and other technological developments.

- $\quad$ Retirement options need to be promoted in TBS, instead of firing from work due to decreasing need for personnel because of digitalization.

- Need for enhanced negotiations, communication, interactions and networks of unions and TBS.

- As experienced during Covid-19, developing a culture of distant working, working from home in TBS.

Policy target in this context is coping with employment effects of new technologies with more competent human capacity, utilizing new employment opportunities

A. C. Yıldırım, "Turkish Banks and Digitalization: Policy Recommendations from a Qualitative Study", Journal of BRSA Banking and Financial Markets, 14, (2), 2020, 145-174 
for developing requirements for new skills. Thus, development of skills and competency of human capacity is important as a social policy, in the era of rapidly changing requirement for skills and substitution of human factor by technology (like Al mainly in finance sector etc.).

These policy recommendations can be extended with more topics. But major headlines of policy development in this regard are mainly as stated above.

\subsection{Conclusion}

These findings and discussions reveal the fact that there is a need for a holistic approach to set up the framework for development of collaboration networks, transformation of legal system, developing entrepreneurship in TBS by supporting Fintechs, revising Regulatory and Supervisory framework from innovation perspective and competence building and harmonization of work-life. In fact, supporting Jakšič et al. (2015) and Vasiljeva et al. (2016) that mention the probable restrictive effect of regulatory framework on banks' innovative processes, the bank directors interviewed in this study also point out the importance of flexibility and adaptation of regulations in the innovation ecosystem. TBS needs a leading actor to set up an innovation framework. Therefore, regulatory and supervisory authorities may have such a role in setting a sectoral innovation system both in Turkey and globally.

In addition, looking at the business model approach, as Ditshego (2018) states and repeatedly mentioned by the current study's interviewees, changes in value creation stemming from digitalization necessitate fast, accessible, and efficient operations that satisfy customer expectations. In this respect, supporting Deloitte (2018), our results show that vertical integration of operational process with specialized partners having cost efficiency in each step of business gains strategic importance.

Hence, this strategic partnership consideration leads to a platform banking approach (Open $X$ ) for sustainable banking services. The new paradigm has been discussed by Capgemini EFMA (2019) as a change in business culture and technology architecture with radical digital transformation. This new development is also mentioned by bank directors interviewed through the needs of collaborating with Fintechs and perceiving them as complementary partners while defining Big Techs and technology companies as potential competitors. To gain a competitive advantage in the sector, banks need to develop and gain experience on tools such as APIs and Al to enhance innovative capacity and customer experience quality. As mentioned by the interviewees, regulatory authorities are expected to provide safe and transparent environment for these new technological transformations. 
For further studies, the effect of Covid-19 experience on policy development, competence building, harmonization of work-life and working relations in the context of digitalization are other important issues to be considered. The impacts of digitalization and Covid-19 on the business models of banking sector has been explored recently (Yıldırım, 2020) and will be searched by many other qualitative and quantitative studies in the aftermath. 


\section{References}

1. Accenture, (2017), Redefine Banking with Artificial Intelligence, www.accenture.com/_acnmedia/pdf-68/accenture-redefine-banking.pdf

2. Akhavein, J., Frame, W.S. and White L.J.. (2005). The Diffusion of Financial Innovations: An Examination of the Adoption of Small Business Credit Scoring by Large Banking Organizations. Journal of Business, 78 (2): 577-596.

3. Capgemini, EFMA, (2019), World Retail Banking Report, www.capgemini. com/news/world-retail-banking-report-2019/

4. Cherowbrier, J. (2020), Number of active mobile banking customers in Turkey 2014-2018, www.statista.com/statistics/888594/turkey-number-of-active-mobile-banking-customers/

5. Comert, H. and Epstein, G.. (2016). Finansal Yenilik Yazınındaki Son Gelismeler, STPS Working Papers 1604, STPS - Science and Technology Policy Studies Center, Middle East Technical University, revised Jan 2016.

6. Davenport, T.H. and Westerman, G.. (2018), Why So Many High-Profile Digital Transformations Fail, Harvard Business Review, www.hbr.org/2018/03/ why-so-many-high-profile-digital-transformations-fail

7. Deloitte, (2018), EMEA Digital Banking Maturity Report, www2.deloitte. com/DigitalBankingMaturity

8. Ditshego, K.J.. (2018). Assessing the Influence of Digital Transformation on Digital Maturity within a Large Corporate Bank, North-West University, dissertation paper, www.repository.nwu.ac.za/handle/10394/30962

9. European Union, (2015), Payment Services (PSD-2) Directive (EU) 2015/2366, www.ec.europa.eu/info/law/payment-services-psd-2-directive-eu-2015-2366_en

10. Gsell, S. and Mette, J.. (2017), The Impact of Digitalization on the Business Model of German Retail Bank,

11. www.lup.lub.lu.se/luur/download?func=downloadFile\&recor$d O I d=8924906 \&$ fileOld $=8924907$

12. Jakšič, M., and Marinč, M.. (2015). The Future of Banking: The Role of Infor- 
mation Technology. The Journal for Money and Banking, 64(11): 68-73.

13. Kalling, T.. (1999). Gaining competitive advantage through information technology: A resourcebased approach to the creation and employment of strategic IT resources. Phd Thesis, Department of Business Administration, Lund University.

14. Oslo Manual.. (2005). Guidelines for Collecting and Interpreting Innovation Data-Third Addition. Organisation for Economic Co-Operation and Development (OECD).

15. Özel, N., Şahin, İ. and Göral, R.. (2017). Türk Bankacılık Sektöründe Etkinlik ve Verimlilik Aanalizinin Veri Zarflama Yöntemi ile Incelenmesi: 2013- 2015 Dönemi Uygulaması. Sosyal Ekonomik Araştırmalar Dergisi, 17: 85-100.

16. Patton, M. Q.. (2002). Qualitative Research \& Evaluation Methods (3rd ed.). London, New Delhi: Sage Publications.

17. Qu, S.Q. and Dumay, J.. (2011). The Qualitative Research Interview. Qualitative Research in Accounting and Management, 8(3): 238-264.

18. Tekeli, E., (2017), İnternet Bankacılığı ve Mobil Bankacılığın Tarihsel Gelişimi. Glokal Web, www.glokalweb.com/yazi-internet-bankaciligi-ve-mobil-bankaciligin-tarihsel-gelisimi

19. Turkish Institute of Statistics (TURKSTAT), (2020), Population Statistics, Main Statistics, www.turkstat.gov.tr/UstMenu.do?metod=temelist

20. Türkoğlu, R.. (2002), Bankaların Verdiği WAP Hizmetlerinin Gelişimi, www. turk-internet.com/bankalarin-verdigi-wap-hizmetlerinin-analizi/

21. Türkiye Cumhuriyeti Cumhurbaşkanlığı Strateji ve Bütçe Başkanlığı, (2019), On Birinci Kalkınma Planı (2019-2023),

22. www.sbb.gov.tr/wp-content/uploads/2020/03/On_BirinciPLan_ingilizce_ SonBaski.pdf

23. TÜSIAD, Samsung Türkiye, Deloitte Türkiye, GFK Türkiye, (2016), Türkiye' deki Dijital Değişime CEO Bakışı,

24. www2.deloitte.com/content/dam/Deloitte/tr/Documents/technologymedia-telecommunications/turkiyedeki-dijital-degisime-CEO-bakisi.pdf 
25. Vasiljeva, T. and Lukanova, K.. (2016). Commercial Banks and Fintech Companies in the Digital Transformation: Challenges for the Future, Journal of Business Management, 11: 25-33.

26. Yin, R. K.. (2014). Case Study Research Design and Methods (5th ed.). Thousand Oaks, CA: Sage.

27. Yıldırım, A.C.. (2019). Digitalization of Turkish Banking Sector: Preliminary Results of a Qualitative Study. International Engineering and Technology Management Summit, Istanbul.

28. Yildırım, A.C.. (2020). The Impacts of Digitalization and Covid-19 on the Business Model of Banking: A Qualitative Study on Turkish Banks. Master's Thesis Middle East Technical University.

29. Yıldırım, O., Ülgen S.. (2006). Türk Bankacıllık Sektörünün Tarihsel Gelişim Süreci. Finans-Politik ve Ekonomik Yorumlar, 43: 46-53. 